\title{
Serine/Threonine-Protein Kinase D1
}

National Cancer Institute

\section{Source}

National Cancer Institute. Serine/Threonine-Protein Kinase D1. NCI Thesaurus. Code C95258.

Serine/threonine-protein kinase D1 (912 aa, 102 kDa) is encoded by the human PRKD1 gene. This protein plays a role in diacylglycerol-mediated signal transduction. 